\title{
Research-Based History Learning Model in SMAN 2 Bantul
}

\author{
Bayu Ananto Wibowo \\ Graduate School \\ Universitas Negeri Yogyakarta \\ Yogyakarta, Indonesia \\ anantabayu687@gmail.com
}

\author{
Djoko Suryo \\ Graduate School \\ Universitas Negeri Yogyakarta \\ Yogyakarta, Indonesia \\ djoko98@yahoo.com
}

\begin{abstract}
The purpose of research was to find out: (1) The implementation of research-based learning model in SMAN 2 Bantul as a learning innovation of Curriculum 2013, (2) The implementation of researchbased learning model in History learning in SMAN 2 Bantul. This research was a qualitative descriptive research using the qualitative approach of case study in SMAN 2 Bantul. Research subjects were the principal, the curriculum coordinator, the History teachers, and the students. The data obtained in the research were in the form of direct information from the subject, the observation and facts documents in the field in accordance with the research focus. The results of the study are as follows: (1) This research-based learning model can strengthen the character education and deepen the knowledge of the students, so that researchbased learning model can be a role model for other senior high schools. (2) In History learning, this research-based learning model can improve students' thinking ability that can be seen from their ability in discussing and expressing opinion that was much better than before. The research-based learning model applied to the History learning created a new learning model that was named the Research-Based History Learning Model.
\end{abstract}

Keywords - research-based learning model, History, character education, knowledge

\section{INTRODUCTION}

In the world of education, one of schools' keys to determine the quality of education is to use a learning program. Since this matter is important, each school has a variety of ways, strategies, and approaches of learning for it to be maximized and effective. Therefore, in the real practice, schools must adapt to the implemented curriculum [2].

The curriculum is very important in fulfilling the mission of the school, since it is the primary medium to achieve the goals and objectives of the school. The focus on curriculum planning and development is certainly a top priority of educational reformation [9]. Therefore, the curriculum is mandatory to be evaluated and improved every year in order to achieve the desired goals.

In Indonesia at the academic year of 2013/2014, Curriculum 2013 was implemented even though it was limited. Only some schools that were ready to implement it could use Curriculum 2013 and in the same time they could also be the example for other schools that were still in the development stage from the KTSP 2006 curriculum towards Curriculum 2013. In Curriculum 2013, character education is the primary concern. Until today, Indonesian education is still experiencing difficulties in producing qualified, capable, and creative graduates who can serve as a source of motivation in various fields of development. Hence, an effort is needed to make schools produce graduates with quality and character [17].

The addition of the character education into the school curriculum has become an increasingly popular response. This was because of their high emphasis on achieving high academic achievement, leaving small attention to the development of socialemotional competences [5]. The main consideration of the curriculum changes from KTSP 2006 to Curriculum 2013 was because of the character reason. Some people argue that KTSP 2006 is too focused on cognitive, contains heavy students' obligations, contains less character values, and is less sciencetechnology and faith-piety oriented [12].

The importance of character education for students is explained in Regulations No. 20 of 2003 on the National Education System in Article 3 that state that the function of national education is to develop the ability and form the character and civilization of dignified nation in order to educate the nation. Under the law, character education is one of the goals of national education. This means that national education not only is focused on intellectual intelligence alone, but also leads to the formation of the character of students through character education. Education not only is the implementation of teaching and learning process to gain students' intelligence, but development of other potentials owned by the students so that they could have positive characters.

Character education has recently regained importance in education [8]. Where in some countries around the world, education has two big goals: (1) to help young people become intelligent; and (2) to help them to be good [18].

Character education is used to shape one's personality through character education, whose results are seen in one's actual actions, good behavior, honesty, responsibility, respect for the rights of others, hard work, and so on [15]. Other than that character education or the so-called character teaching, is used to support the development of the 
lives of children, physical and spiritual, from their natural characteristics towards good characters. He adds that character education questions and teaches all the properties and forms of goodness in human life, not only to be known and understood, but also permeated and desired until it is done by people [3].

Character education that becomes the focus in Curriculum 2013 makes every school demanded to be creative and innovative related to learning models so that the character values can be implemented. Schools must provide character education facilities for the students. School is one of the important parts of the development of the students, the teaching of characters or morality is still a concern in our everchanging world. Since morality is largely an unwritten interaction between people of the same culture, creating an area where students can share and discuss is considered important. Morality and social responsibility relate well to the teacher and to the students' home environment because teaching is an important part of moral development [14].

In the Curriculum 2013, character implementation has been tucked into every subject that will be taught in school, for example the History subject. In learning History, students are required to think critically, therefore it requires learning strategies, methods, or learning approaches that can be packed into a model of learning in order to help students in learning, being creative, and to help them to think critically while also implementing character education on the learning process.

Through learning History, it is expected that learners can develop historical intelligence through critical, creative, and imaginative thinking. With a historical intelligence, one can understand every phenomenon and socio-national events carefully, clearly and comprehensively so it could give birth to a wisdom and history in depth [19].

To maximize the role of learning History in Curriculum 2013, it is necessary that learning models should be used as the reference for other schools in order to maximize the implementation of Curriculum 2013. Furthermore, Curriculum 2013 is still dynamic and can change, the reference can be proposed as an effort to improve the curriculum.

One innovative effort to maximize Curriculum 2013 and History learning is the application of research-based learning. Research-based learning or Pembelajaran Berbasis Riset (PBR) is one of StudentCentered Learning (SCL) methods that integrates research into the learning process. $P B R$ is multifaceted referring to various learning methods [1]. Furthermore, research-based learning $(P B R)$ is a learning method that uses authentic learning, problem-solving, cooperative learning, contextual (hands on \& minds on) and inquiry discovery approach guided by the philosophy of constructivism [4].
Research-based learning is based on a constructivism philosophy that includes 4 (four) aspects: learning that builds learners' understanding, learning by developing prior knowledge, learning which is a process of social interaction, and meaningful learning that is achieved through a real experience. Other than that, research-based learning model is a type of learning that is based on research with three stages: the first stage is the exposure stage, this is a stage to find out the ability of the students; the second stage is the experiment stage that is the provision of experience with research; and the third stage is the capstone stage that presents research results, oral and written [11].

Research-based learning (PBR) is one of StudentCentered Learning (SCL) methods that integrates research in the learning process. $P B R$ provides opportunities or chances for students to seek information, develop hypotheses, collect data, analyze data, and make conclusions on the data that has been arranged. The approach of "learning by doing" is applied in this activity. The implementation of this research-based learning model will provide benefits for the students, teachers, and school [11].

This research-based learning model requires learners to discover their own knowledge, attitudes, and skills as a manifestation of behavioral change. Therefore, learning by using this model requires the maximum involvement of learners throughout the ability of learners to seek and investigate systematically, critically, and logically against a phenomenon to find what is desired. In other words, learners will develop their ability in the learning activities. Learners are more independent to learn and more creative in learning activities in class [20].

In line with any new approach, implementation problems can always be identified, but if it is innovation, students will struggle with ideas that are randomly driven. Such conditions are often difficult for individuals to start and tolerate because students do not yet know the purpose of the goal. Therefore, orienting a wider idea in a critical thinking system is important, because it gives students the metacognitive "anchor" of that increase their tolerance to ambiguity. This is done by demonstrating how critical thinking can be used to increase generative capacity (creative) and how they can be used more "traditional" to increase evaluative capacity during the future feasibility analysis linked to ideas [13]

To facilitate research-based learning applied to the learning of History subject in school, the method needs to be modified into a model of learning, for example the research-based learning model implemented by SMAN 2 Bantul as a form of innovation to maximize character education and knowledge in Curriculum 2013. Moreover, SMAN 2 Bantul is considered as a top level senior high school that is a favorite school for learners in Bantul. 
Furthermore, in the regency, SMAN 2 Bantul is one good example of schools in the implementation of Curriculum 2013 for senior high schools. SMAN 2 Bantul is the only senior high school in Bantul that uses a research-based learning model in its learning process.

Research-based learning model is considered effective in strengthening the character and knowledge of students, with the hope that their characters and knowledge will be more enhanced so that in addition to having the character values of Curriculum 2013, the students also begin to form the soul of scientists. Especially in learning History subject, character values such as the value of tolerance, the spirit of nationalism, and love of the homeland can be maximized. Besides, this research-based learning model can be a reference for other schools in Bantul district that will implement Curriculum 2013 but still find difficulties in maximizing the learning process.

\section{RESEARCH METHOD}

This research uses qualitative approach of case study in SMAN 2 Bantul on learning History subject. According to Gumilang, qualitative research has two main characteristics: first, the data is not in the form of numbers, more in the form of narrative, description, story, written and unwritten documents; second, qualitative research has no absolute formula or rule for processing and analyzing data [6]

This research entitled "Research-Based History Learning Model in SMAN 2 Bantul". The reason for the use of this type of qualitative research case study is because this study aimed to reveal the data in depth about a phenomenon. Based on this approach, it is expected that Research-Based History Learning Model in SMAN 2 Bantul can be described more thoroughly and deeply.

The data obtained in the research are direct information from the subject and the observation and facts documents in the field in accordance with the focus of the research. The researcher used purposive sampling technique where the informants were the sample criteria desired by the researcher. The informants as the data source of the research are the principal, the curriculum coordinator, the History teacher, and students of SMAN 2 Bantul.

The data collection technique is the most important step in research. Without knowing the techniques of data collection, the researcher will not get the data that meet the standard data set. In qualitative research, collecting data is done on natural settings (natural conditions), primary data source, and the data collection techniques are derived more on observation, interviews, and documentation [22].

The process of collecting data in this research location is described as follows:
1. Conducting initial observation with an informal approach by meeting the history teacher. The researcher firstly introduced himself and expressed his purpose and goals.

2. Doing a formal approach with legal permission letter. After formally submitting the permission letter, the next step was approaching the respondents who will be the informants with prior consultation with the History teacher.

3. Conducting research activities. Data collection techniques used by researchers are described as follows:

\section{a. Observation}

Observation or direct observation is a research activity conducted directly to observe the social phenomena that occur in the field. In this observation, the researcher directly observed the location of the school as well as the predetermined model of the research-based learning model. Observation is a data collection technique that requires the researcher to go to the field to observe things related to space, place, people, things, time, events, goals and feelings [21]. In this research, objects that were being observed are the location of schools, facilities and infrastructure that support the implementation of research-based schools, as well as the tools or media of History subject learning in SMAN 2 Bantul.

\section{b. Interview}

Interview is a conversation with a specific purpose. The conversation is conducted by two parties: the interviewer who asks questions, and the interviewee who is being interviewed or who provides answers to the questions asked [21].

In this interview technique, the first step was verbal question and answer stage with the informants in the form of systematic questions related to the problem and it became the objectives in this research with the guidelines of interviews that have been arranged and formulated properly.

\section{c. Documentation}

The research document is a complement of the use of observation and interview methods in qualitative research [22]. In this research, the complementary documents are RPP (lesson plans), syllabus, product of assessments of the students (scientific research), Design of Research-Based Schools, and photographs of the facilities and infrastructure that support research-based learning.

Data collection technique used in the research were: interview with principal, teachers, and students in SMAN 2 Bantul. After the data were obtained, they will be described and analyzed.

In qualitative research, data are obtained from various sources by using data collection techniques 
that vary (triangulation). The data analysis is the systematical process of searching and compiling data obtained from interviews, field notes, and other materials, so that they can be easily understood, and their findings can be informed to others [22]

This research used qualitative data analysis techniques. The data were processed so that conclusion or valid meaning can be derived. The process of testing the validity of the data conducted in this study include the data triangulation techniques and reference materials i.e. supporting evidence from the data obtained by researchers in the form of interview summary, photographs, field notes from observations, and documents from schools such as educational curriculum, event notes, research format, and many other. The stages of data analysis used in this research include:

1) Pre-field analysis, that is the data obtained from preliminary studies, or secondary data that will be used to determine the focus of the research although this focus is temporary.

2) Analysis during the field according to Miles and Huberman model, that is the analysis performed during the data collection process and after the it has finished within a certain period.

\section{RESEARCH-BASED LEARNING MODEL AT SMAN 2 BANTUL}

Currently, the national education faces various challenges, especially in preparing the quality of human resources to be not only productive but also having characters. To be productive, people should not only be given expertise skills, but also character education as the guide in work ethic [16].

The implementation of Curriculum 2013 is an effort from the government effort to shape students who have the skills and the characters in response to the challenges of the world situation right now. The reasons for the development of Curriculum 2013 are: First, future challenges include the flow of globalization, environmental issues, advances in information technology, convergence of science and technology, and knowledge-based economy. Second, the future competencies that include communication skills, the ability to think clearly and critically, the ability to consider the moral side of certain problem, and the ability to try to understand and be tolerant to different views. Third, social phenomena that surfaced such as student brawls, drugs, corruption, and social unrest. Lastly, it is public perception that education is overly concerned with cognitive aspects, students' obligations that are too heavy, and the lack of characters [10].

Character education of Curriculum 2013 must be well received by students. In order to be well received, each school is suggested to have some learning methods that can stimulate the ability and creativity of the students and make them have the characters as desired by Curriculum 2013 [7].
The research-based learning model implemented in SMAN 2 Bantul is an answer to the challenges given by the curriculum that demands that schools have creative and innovative learning as well as character education implementation to the students. This learning model was implemented in 2013. As the school that became the role model of the Curriculum 2013 implementation, SMAN 2 Bantul should have learning models that can stimulate students' activeness as well as implement the 18 characters values desired by Curriculum 2013.

To support the implementation of this researchbased learning model, SMAN 2 Bantul designed the design of "Research-Based School" which is the rule and guidance for both the teachers and the students. Explained are the efforts of SMAN 2 Bantul in applying the research-based learning model.

\section{a. Teacher research training}

SMAN 2 Bantul teachers are suggested by the principal to apply creative learning models that can attract students and stimulate their curiosity so that the character education will be easily embedded in them. Hence, research-based learning model is applied. Before implementing this learning model, teachers were given a research training by the cooperation between SMAN 2 Bantul and the lecturers from Islamic University of Indonesia (UII). The training was conducted to train the teachers of SMAN 2 Bantul in teaching the students to conduct research that can then be justified.

\section{b. Research teachers}

There were 22 teachers who were given the responsibility to teach the subject of research at SMAN 2 Bantul. The duty of research teachers was to guide students from the stage of introduction to research, conducting research, writing reports, to being responsible for its findings.

\section{c. Research extracurricular activity that is being regularized}

Regularized research extracurricular activities were developed following the Teaching and Learning Activities (KBM) with 2 lesson hours per week and allocated for grade $\mathrm{X}$ students. This regularized research extracurricular activity became something unique in SMAN 2 Bantul since it is the only school in Bantul that has research learning. As expressed by Curriculum Coordinator of SMAN 2 Bantul, this research learning was formed as the school's effort to introduce research to students, ranging from the introduction of research, writing research proposals, going into the field, until finally presenting the results of their research.

This regular activity was available only for grade $\mathrm{X}$ students, as the introduction to research until the real practice in the field, hoping that when they become grade XI and XII students, this researchbased learning can be applicable to each subject so 
that students will no longer find difficulties when the teachers apply the research-based learning.

\section{d. Research extracurricular (Research Club)}

To support the students' interest in research, SMAN 2 Bantul formed a Research Group or Research Club where learners can submit their research findings to be later submitted in scientific writing competitions. The result is quite a pride for the school. SMAN 2 Bantul got the third-place winner in national level.

\section{e. Facilities and infrastructure that support the research-based learning}

To support the research-based learning, SMAN 2 Bantul provides facilities and infrastructure that can be utilized by the students. Described are the facilities and infrastructure that support the research-based learning in SMAN 2 Bantul:

\section{1) Laboratory}

There is a representative laboratory to support the teaching and learning process. The laboratory is used both in learning activities and research development for the students of SMAN 2 Bantul. There are physics laboratory, chemistry laboratory, biology laboratory, language laboratory, social sciences laboratory, computer laboratory and multimedia laboratory.

\section{2) Prapanca Library}

The library of SMAN 2 Bantul is in Dewi Sartika building and has a collection of thousands of books. Equipped with air conditioners and internet, SMAN 2 Bantul's library has been using digital system until now. There is also one reviewer room with the capacity of 40 people equipped with a LCD projector, air conditioners, and computers, so it can also be used for learning.

\section{3) Reading Corner}

There are many places to read in SMAN 2 Bantul. These corners are made as comfortable as possible to make it easier for students to read and look for references.

\section{4) Research Club Room}

This research room is established for the activities of students who are the members of the research club. Beside their main duty in making scientific research, they can also have discussions and submission of the results of other students' research to be later registered in the scientific research competition. The committee members of the research club are the students of SMAN 2 Bantul itself.

\section{5) Scientific Research Competition}

SMAN 2 Bantul has always been a participant in the of scientific research competitions. There are many achievements of the students who successfully won the scientific research competition in the national level. For students, this is a very valuable experience whose research can be continued in their university level one day. In addition, the ability in critical thinking of the students will be much better, they can also strengthen the values of the character in Curriculum 2013 and deepen its science.

\section{RESEARCH-BASED HISTORY LEARNING MODEL IN SMAN 2 BANTUL}

From the observation of the lesson plan-syllabus documents and the results of interview with the teacher of History subject, a new learning model resulting from a research-based learning model that is implemented in History subject learning was found. The discovery was named Research-Based History Learning Model.

Research-Based History Learning Model is one of student-centered learning (SCL) methods that integrate research in History learning activities. This model is multifaceted in reference to various methods of learning. This model provides opportunities or chances for students to seek information, develop hypotheses, collect data, analyze data, and make conclusions on the data that have been compiled. This activity applies the learning approach of "Learning By Doing". The implementation of the Research-Based History Learning Model will provide benefits for History learning, the students, History teachers, and school.

In the application of Curriculum 2013 that focuses on character education, this research-based History learning will be effectively applied. Research-based learning requires learners to be able to find their own knowledge, attitudes, and skills as a manifestation of behavioral changes. Therefore, learning by using this model requires the maximum involvement of learners throughout their abilities to seek and investigate systematically, critically, and logically against a phenomenon to find what is desired. In other words, students will develop their ability in the learning process. Students will be more independent to learn and be more creative in learning process in the classroom [20].

The research method used in this model was historical research method. The method of historical research is the method used in the research process of past sources that is used critically, analytically, and systematically and presented in written form. Historical research method is divided into 4 stages, they are:

\section{a. Heuristics (data collection)}

Heuristics is the activity of finding and collecting the necessary resources.

1) Primary source

2) Secondary sources 


\section{b. Verification}

Verification is a source-criticism activity to test the accuracy/authenticity and credibility of the source.

1) Internal criticism

2) External criticism

\section{c. Interpretation}

Interpretation is an activity to interpret or find the meaning of facts and the relationship between one fact and another.

\section{d. Historiography}

Historiography is the process of arranging fact and their meanings chronologically/ diachronically and systematically into historical writing as a story.

In applying the model, the teacher acted as a mentor by giving the students the opportunity to actively learn, as how the teacher's opinion should be able to guide and direct students' learning activities. The teacher started the learning process with several stages such as beginning with the preparation process, either from the program development such as lesson plan in which its preparation is already done before the learning process is implemented. The lesson plan itself can be used as the guide for the teacher in carrying out the learning activities that lead to a scientific approach, including observing, questioning, gathering information, associating and communicating.

The learning activities of History subject arranged in the lesson plan were divided into two points, namely: (1) The initial activity, where the teacher started from starting the learning process, providing motivation to students; (2) The core activities, in which in the teacher was no longer the only source of learning but he/she guided the students to be able to actively seek, collect, and develop the materials they obtain.

Ultimately, the goal in the Research-Based History Learning Model was to strengthen the character education of Curriculum 2013 and to deepen its knowledge. Then, in its application in school, this model can be the example of effective History learning activities.

\section{CONCLUSION}

Based on the results of the study, it can be concluded that by applying the Research-Based Historical Learning Model, character education in the 2013 Curriculum can be strengthened and the knowledge can be learned in depth by students. The use of this model can really change the conditions of learning to be passive to be active and creative, from teacher-oriented learning to student-oriented learning, then SMAN 2 Bantul can be an example for other schools that implement the 2013 curriculum, but still have difficulties in choose the right learning method and can strengthen character and deepen student knowledge

In its application in school, in addition to have the character education of Curriculum 2013, this research-based learning model can deepen the knowledge of the students as well. It was because this model has indirectly enhanced the ability of the students affectively and cognitively. Through research tasks, students have strengthened the character education as well as deepened their knowledge. The character values of curriculum 2013 that students can obtain through this research-based learning model include being religious, honest, discipline, hardworking, creative, self-democratize, knowledgeable, achievement appreciative, communicative, love to read, environmental care, social care, and responsible.

In the process of learning History, this researchbased learning model can improve students' critical thinking skills that were visible from the learner's ability to discuss and express opinions much better than before. In addition, students' interest in history has increased with the strengthening of the characteristic values of the spirit of nationalism, the love of the homeland, and the love of peace and tolerance.

The research-based learning model that is implemented in this History learning created a new learning model named Research-Based History Learning Model.

\section{REFERENCES}

[1] Achmadi, et al. Buku Panduan Pelaksanaan Student Centered Learning dan Student Teacher Aesthetic Role Sharing (STAR). Pusat Pengembangan Pendidikan Universitas Gajah Mada, 2010.

[2] Agung, Leo. Sejarah Kurikulum Sekolah Menengah di Indonesia. Yogyakarta: Ombak, 2015.

[3] Dewantara, Ki Hadjar. Pendidikan: Pemikiran, Konsepsi, Keteladanan, Sikap Merdeka. Yogyakarta: UST-Pers, 2013.

[4] Diah, et al. Pedoman Umum Pembelajaran Berbasis Riset. UGM: 2010.

[5] Dodds, Diane M. The Effects of Character Education on Social-Emotional Behavior. Master of Arts in Education Action Research Papers, 2016, pp. 137.

[6] Gumilang, G. S. Metode Penelitian Kualitatif dalam Bidang Bimbingan dan Konseling. Jurnal Fokus Konseling Volume 2 No. 2, Agustus 2016, pp. 144-159

[7] Gunawan, Heri. 2014. Pendidikan Character: Konsep dan Implementasi. Bandung: Alfabeta

[8] Graff, Chelsea E., "The Effectiveness of Character Education Programs in Middle and High Schools", Counselor Education Master's Theses, 2012, pp. 127

[9] Henson, Kenneth. Curriculum Planning: Integrating Multiculturalism, Constructivism, and Education Reform. United States of America: Waveland Press, 2010

[10] Hidayat, Sholeh. Pengembangan Kurikulum Baru. Bandung: PT. Remaja Rosdakarya Offset, 2013. 
[11] Hironimus, Tangi. Pengaruh Model Pembelajaran Berbasis Riset Terhadap Hasil Belajar Mahasiswa Kimia. Jurnal JIPERA Vol 1 Jilid 1 2016, pp. 16-22

[12] Idi, Abdullah. Pengembangan Kurikulum: Teori dan Praktek. Jakarta: Raja Grafindo Persada, 2014

[13] Kevin, et al. Thinking Innovatively about Teaching Innovation and Ideation: Getting Students to Think Differently. Journal of Research in Innovative Teaching. Volume 7, Issue 1, 2014.

[14] Kinkopf \& Casey. Character Education: Teachers Perceptions of its Implementation in the Classroom. Delta Journal of Education. Volume 6, Issue 1, Spring, 2016.

[15] Lickona. Pendidikan Karakter: Penduan lengkap mendidik siswa menjadi pintar dan baik. Bandung: Nusa Media, 2013.

[16] Marlina, M. E. Kurikulum 2013 Yang Berkarakter. JUPIIS. Vol. 5 No. 2, 2013.

[17] Muhtar, Tatang. Analisis Kurikulum 2013 Ditinjau Dari Aspek Nilai Karakter Bangsa. Jurnal Mimbar Sekolah Dasar, Volume 1 Nomor 2 Oktober 2014, pp. 168-175

[18] Noviani, Nita. Bildungsroman for Character Education in Higher Education: an Indonesian Context. International Journal of Education Vol. 9 No. 2, Februari 2017, pp. 126132

[19] Sardiman. Menakar Posisi Sejarah Indonesia pada Kurikulum 2013. Jurnal Pendidikan Sejarah, Fakultas Ilmu Sosial, UNY) Volume 11 No 1 September 2015.

[20] Sigit. Pembelajaran Berbasis Riset. Jakarta: Akademia Permata, 2013.

[21] Suganda, Romi. Pengelolaan Sarana Berbahasa Inggris. Jurnal Studi Deskriptif Kualitatif, 2013.

[22] Sugiono. Metode Penelitian Pendidikan. Bandung. Alfabeta. 2016, pp. 309-334 